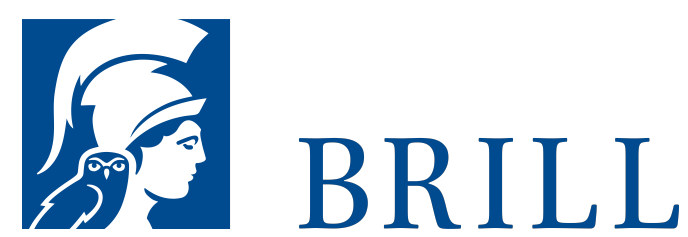

\title{
Einige Wiener Papyri (P.Vindob. Boswinkel)
}

\author{
Author: Boswinkel
}

Language:

German

Subjects:

General,

Classical Studies

Publisher: Brill

Series:

Papyrologica

Lugduno-

Batava, Volume:

2

E-Book (PDF)

Released online: O2 Mar $202 \mathrm{O}$

ISBN: $978-90-$

04-42992-5

List price

USD $\$ 42.00$

Hardback

Publication date: o1 Dec 1942 ISBN: 978-9004-42877-5 
For more information see brill.com

Order information: Order online at brill.com +44330 333 0049 | customerservices@brill.com Submission information: brill.com/authors

Titles published by Brill | Fink, Brill | mentis or Brill | Schöningh: +49(o)715413279216| brill@brocom.de 